\title{
COMPLEMENTARITY OF SOURCES IN STUDYING ADAPTATION: AN ORAL HISTORY VIEWPOINT
}

\author{
Tiiu Jaago \& Ene Kõresaar
}

\begin{abstract}
The purpose of this article is to elucidate the complementary nature of two types of sources: First, an autobiographical narrative about the Soviet period written in 2005, 14 years after the period described. Second, a court file created by the representatives of Soviet authority from their point of view and containing material from the period 1945-1994. Both documents represent very different genres, are temporally different, have different purposes, and different viewpoints. Inspired by the work of Alessandro Portelli, particularly by his model of multilayered history-telling, the method of separating texts in three layers, institutional, communal, and personal, is used. The central question about the possibility of complementary treatment of diverse sources in oral history is posed against the background of researching adaptation to the Soviet regime. Asking a direct question will not offer the researcher very much information about actual adaptation or inadaptability because the respondents will be affected by their attitude towards, and the act of remembering, the Soviet regime. Therefore, in the present study the language of written texts is chosen for analysis pointing out that two contrary concepts characterise adaptation to Soviet authority: opposition that disputes the authority's point of view, and the inability to phrase phenomena in the 'non-Soviet language'. Additionally, the problem of individual agency in encountering the repressive ideological and societal system as expressed in the sources both diachronically and synchronically is discussed.
\end{abstract}

Key words: adaptation, life history, oral history, post-Soviet studies, source criticism

\section{INTRODUCTION}

This article is a reflection on a process of studying Estonians' adaptation to the Soviet regime from the perspective of oral history in the way it offers a methodologically new treatment of different types of sources. The focus of the article is twofold: firstly, it aims at elucidating the possibility of complementary analysis of a contemporary autobiographical narrative and a historical court file in order to, secondly, draw conclusions about the adaptation processes in Estonia since 1945 from the perspective of an individual. 
The idea for the present article arose from a report given in November 2007 at a conference of oral history in Cracow. ${ }^{1}$ We spoke of a dialogue in the oral history sources where the linguistic performance originates from different images or "pictures" of history. We were interested in the way that people adapted to the "Soviet way of thinking". This theme does not automatically present itself to the researcher. If we ask a direct question of how an individual adapted to the Soviet regime, the answer will be affected by the individual's attitude towards the regime as well as to the actual discourses of remembering. For this reason, we studied the same process 'indirectly', using the linguistic level. ${ }^{2}$ For our sources we have used two written texts of a very different kind: an autobiographical narrative sent in to a public competition at the Estonian Literary Museum in 2005, and a court file, assembled by the Soviet organs and held at the State Archives, containing documents from the period of 1945-1994. Our purpose was to study how people's adaptation to a 'language' alien to them is expressed. The first document, the autobiographical narrative enabled us to consider adaptation synchronically by observing different styles that make up the narrator's text and the narrator's presentation of the roles of those who "speak" in these styles. The other document, however, made it possible to follow the problem diachronically and, at the same time, in a situation where the parties of the dialogue (and their language usage) are in conflict. ${ }^{3}$ We found the theoretical framework for our research from the works of Yuri Lotman in which the exchange of information (language, culture) in border situations, as in the encounter of different cultures (languages) is described (Lotman 1994; 1999, especially pp. 14-15). This enabled us to view such conflicting situations within the context of Soviet power and Estonian culture.

From the feedback to our research presented at the Cracow conference we came to an understanding that a court file as a source is not necessarily recognizable from the point of view of oral history. Both sources inspired us to study adaptation resulting from the conflict; the difference in the genre of the sources, however, was perceived by our audience as non-compatible for the purposes of oral history. The different notions of oral history underlying this misunderstanding seems evident: 'oral history' in English means mainly an oral narrative of the past, the basic source of which is an interview (Portelli 1997a, Grele 2007); the similar, implicitly formed research in the humanitarian and social sciences, focusing on popular understanding of history are not called 'oral history' in other languages (cf. Thompson 2000 [1978]; Burke 2004; Fingerroos et al. 2006). Estonian 'oral history' tradition belongs to the second category, assuming the use of different sources, including written and archival ones (Jaago 2001; Jaago et al. 2002; Jaago et al. 2006). We thus needed to find a way to describe these sources to the researchers of oral history in a way that they 
would understand. At the same time, we had to make these texts which, not only by their structure but also their time and purpose of creation are totally different, comparable in presenting the results of our research.

A solution seemed to be 'translating' the sources of a seemingly non-oral historical nature into the language of oral history. For this purpose, we relied on Alessandro Portelli's classic narrative modes of history-telling. Here speaking about history is distributed analytically between three layers: institutional, communal, and personal. ${ }^{4}$ In the following article we have based our description of sources on Portelli's model, ${ }^{5}$ while at the same time keeping the basic question of adaptation. Our purpose is to unfold atypical sources from the perspective of oral history and analyse them within the classic theoretical frame of oral history. Bringing together Lotman's theory which makes it possible to describe the encounter of different 'languages' in a conflict situation, and Portelli's approach where history-telling is divided between the institutional, communal, and personal layer, the complex relations of all these layers in a conflict situation are brought forth and can then be studied by applying the notion of adaptation.

\section{ORAL HISTORY AS MULTIVOCAL DISCOURSE: A MODEL FOR COMPLEMENTARY TREATMENT OF SOURCES}

Portelli's tripartite mode of history-telling is based on an understanding that it will not be sufficient in studying oral history if we only frame the individual narratives with the dynamics of history. Portelli treats a personal oral narrative as a structurally complex text where changes in language usage and definition of time also denote changes in experience (which in its turn is also structural). The characters, space of action and grammar of a story alternate according to the point of view the story is told from. Thus Portelli differentiates between institutional, communal, and personal layers which manifest themselves as certain tendencies and are never quite separable. Conversely, the meaning of history in these narratives exhibits itself in a combination of these layers. The story in the institutional mode is told impersonally in the third person and considers what happens at the state or national level (in the ideology and political activities of the government, the parties and/or the trade unions). The story in the communal mode involves the immediate environment, the community (town, neighbours) and working life where the narrative mainly uses the communal 'we'. The story's focus in the personal mode is the home (private and family life) and the events of personal life (such as instances 
of death, birth, jobs, children, etc.) but also personal attitudes towards the first two layers with the narrative using the first person singular (Portelli 1997b: 27). Our method treats the official (Soviet) state viewpoint in an Estonian context as the institutional layer; the locality (village, commune) and the general ethnic Estonian community as the communal layer and private and family life as the personal layer.

The pre-requisite of applying the whole model is language, as concluded from Portelli's understanding of genre:

If we define genre as a verbal construct shaped by shared verbal deviceswhether conventionally established or not - oral history is then both a genre of narrative and historical discourse, and a cluster of genres, some shared with other types of discourse, some peculiar to itself (Portelli 1997a: $3-4)$.

Language is fundamental in pointing out the narrative point of view, be it institutional ("they would go", "they", "you"), communal ("we"), or personal ("I"). Our method also concentrates on language where we first delineate the point of view of the first-hand narrator and narrative ("they", "we", "I"). In our sources, however, the conflict of naming the phenomena and situations is in the foreground and causes a concentration of the treatment of the complex level of notions and linguistic forms. This, in turn, opens up a deeper level of the narrator's and narrative's point of view.

Portelli's model has been developed on the basis of a typical oral history interview (1997a: 4), which means that Portelli has defined oral history, especially the basic sources in a way different to us. Portelli characterizes the oral history interview in the context of everyday life as exceptional: the tale in a typical oral history interview has never been told entirely before. Oral history (and life story), as a coherent narrative, does not occur in everyday life in its "natural status", because it is a "synthetic product of social science". To understand this through analysis one must navigate the area between textual experiment and frozen formulaic material and finally must not forget the role the historian plays in the interview. This is what makes oral history a "multivocal discourse", which differs from other traditionally recognized genres (the fairy tale or epic) by its original cultural position: oral history begins in the orality of the narrator but is directed towards (and concluded by) the written text of the historian (Portelli 1997a: 5).

However, a written autobiography and an official interrogation transcript are in our opinion not so very different from documents created on the basis of an oral history interview. Both sources are "initiated" in an oral situation, be it a situation of interrogation or the everyday autobiographic repertoire of a nar- 
rator. In all three cases, we dealt with documents that, viewed from the aspect of oral history, have been created in order to speak about the past.

Naturally, the role of an oral history researcher is limited, or non-existent in creating the sources we use. ${ }^{6}$ The oral history interview is borne out of the co-operation of two "authors" including both the level of narration (the interviewee-narrator) and the analytical treatment of the theme (the interviewerresearcher). Ronald Grele (2007) has emphasized that an oral history interview as a verbal text has been created as a shared authorship. This, on the one hand, infers using the story-language of the narrative as well as the academic language, but on the other as an interpretation of events by both the individuals who experienced them and the theoretical aspect of the academic researcher (Grele 2007: 13-14). This also means that creating an oral history document is more dynamic than creating the texts we discuss, as the researcher can in the course of an interview ask complementary questions and, if necessary, formulate the text according to their interests. Furthermore, this dynamism makes possible a different method of interpretation, as a researcher who has participated in creating the studied text can, as early as in the course of the interview, check the validity of his/her understanding. Researchers of texts that already exist do not have this possibility; indeed our material was created without the researcher's immediate participation as sovereign texts. Here the self-control of the researcher (their interpretation's probable validity) is dependent on finding the story's point of view, ${ }^{7}$ comparing it to other viewpoints and finding the contexts that cause any differences. Therefore researching oral history hypothesizes comparing different viewpoints and creating a more general historical and textological context, which in turn puts forward a complex use of sources of a different type (see also Jaago 2006).

While demonstrating the applicability of his model in greater detail Portelli shows that in telling about critical or conflict situations the three analyzed layers will come forward more clearly and powerfully:

In many oral history narratives, all modes converge not only on pivotal events, but also on crucial themes. War, for instance, has such a total impact that it can be narrated in all modes: "Mussolini ruined the country" (institutional); "Our town was destroyed" (communal); "I lost a son" (personal). (Portelli 1997b: 34)

Portelli took into consideration both the theoretical model and the narration and saw conflict as the nodal point of narration where all three modes are concentrated and support each other (in solving the conflict). Portelli calls such nodal points or events 'places of memory' where all modes - institutional, communal, personal - come together, as if all meaning converge (Portelli 1997b: 
33). The conflict and adaptation that occur during a long adversarial period was the issue of our hypothesis for which we found relevant sources: (1) A court file had been opened, in 1945, in a conflict situation (during the wave of political arrests after reinstating Soviet order in Estonia), and (2) in 2005, reminiscences about that period of conflict were written in the form of an autobiographical narrative. The latter is retrospective, as by the time of writing the conflict had remained in the past, being real only in the after-effects. The remaining aspect essential to our study was that layers in Portelli's model of history-telling should be clearly traceable and interwoven in those two sources.

In what follows we will describe both sources, demonstrating first how Portelli's layers are represented in them and later how adaptation within these layers can be linguistically observed. We shall not present the sources chronologically (a method of presentation we used in our first article which focused on adaptation) but start with the source typologically most similar to classic oral history and Portelli's theory - the autobiography. Then we shall analyze the court files which do not include narratives; they become a source of oral history due to the researcher asking questions. The habitual view of such documents is, within the context of political history, institutional. ${ }^{8}$

As a novel approach, we regard the material of the court file from the personal perspective, which in the case of an autobiography is self-evident. The court file has an interesting aspect in regard to Grele's (2007: 13-14) "shared authority" argument in the concealment of the interpreter and the recorder. Differences in the two sources not only enabled us to explain the theme of adaptation but also check whether our interpretations about adaptation differ according to, or are independent of, genre specificity.

\section{POST-SOVIET AUTOBIOGRAPHY}

The main theme of the post-Soviet autobiographies of Estonians is the relationship between the narrator and their relatives (or ethnic group) and the Soviet power. People describe how they interpret their relationship with the regime (as a rule, they are ignorant about the existence of court files). Autobiographies are retrospective, which means that descriptions of 'the future' are about known events. That is the reason why the dialogical dynamics of the different layers (personal, communal, and institutional) are syncretistic in autobiographies. They are expressed through images of memory where texts originating from different periods and systems all fit into a coherent system. We cannot reach conclusions about the adaptation process if we follow the same chronological principle the author of the autobiography follows. Before 
creating this definite autobiographical text, an opinion of official texts (notions) must exist. So we can handle the adaptation of the author of an autobiography as a fact of linguistic and notional experience and make observations about the form the text displays.

We chose for analysis a text from the collection of Estonian Life Histories preserved at the Estonian Cultural History Archives, in Tartu, Estonia, an autobiography written in 2005 by Urve Pärt born in $1939 .{ }^{9}$ First we analyzed the autobiography supported by Mikhail Bakhtin's concept of dialogic between texts and within text (Bakhtin 1987; see also its application in memory studies in Wertsch 2002). This enabled us to view Urve Pärt's autobiographical text as several different dialogically related texts and interwoven voice types which simultaneously, as in the case of an autobiography the interpretation is in retrospect, have been created from this dialogue. We examined the relationships between the different speakers and how Urve described her adaptation to the Soviet regime. Behind our analysis was the question of how the official voice of the Soviet regime becomes 'a thinking device' (Lotman 1994) on an autobiographical and communal level. We viewed Pärt's adaptation as a fact of notional experience in which syncretistic narrative form manifests itself.

Our discussion about Urve Pärt's text, and more generally about the multivoiced character of an autobiographical text, coincided with Portelli's narrative model of oral history. In the present article Pärt's autobiographical text fits particularly well as the different voices here, in certain places, are even presented visually. The latter also points to the narrator's conscious desire to differentiate various voices in her narrative. In her written commentary to the narrative Pärt accounts for her choice to include the opinions of others on the basis that they have also helped to shape her life and understanding of the world (Fig. 1 on p. 24). However, the layers that Pärt created in her text do not completely coincide with Portelli's layers of analysis. Furthermore, from the point of view of our analysis, Soviet rhetoric comes to the foreground, the existence of which, when compared to the 'voices' of her relatives and the village people, Pärt is not so conscious of.

The layers Pärt created in comparison to Portelli's layers of analysis could be presented as follows:

1. The author's voice tells of her and her family's life on the basis of personal or secondhand memories - the personal layer.

2. The author has recorded reminiscences and everyday philosophy from local people whom she presents in her text as the common consciousness of the village people and as the 'collective voice' (of Estonians). The function of this is to comment on the life of the author and her family, 
- Äi see 00 üks loll mood... see cinedese päăle kaibamine. See Ärman pole oskand eesti aegas ka töistega rahus elada mette ...-koguse aeg käis kellegiga kohut. Ma usu, et täma oligid ka, kes Rauna Tani üles andis. No mis vaindlane see Tani oli... vaikne tasane mees...neljakümnemal antsid taale miski ammeti...Mari oli ütlend, et mine-mine jah kommunisti usku, pärast vḯlakse Roomassare, lastakse maha. A'ita vaene oskand mette arvata, et nee sónad varsi täide lähuad.

Ärmanil pidi omal poeg sur vaba-tahtlik olema...nunid pole taris normisi täita.

oli wilu ja sombune ilm, kei juhtusime vahvamaja jueves nägema esti meeste salka ja sakslan' sucurte tumeroheliste sogaväemasinatiga, shoned noormehed istusid vailselt hiviaia peal, teised aga hoiblesid pa. lavesid mingi erilise uljesega. Sinu repertwar taienes sellise lauluga:

Elu see vailo lörri minna, sinna parata li saa, aga laul, mis täidab rinda, alati peab lēolama. Lobus ad inimesed, reibas laul. Ag a miles ei olnud öhus teuda röomer, vaid fälle mingit rilekohtuteunet? - So Alleks ju mopi alla äi käi,ta vist tükkis vanem? Toumbi poisid olla jooksus, pole mette käsku täitnd. Kurati sakslane, meid eestlasi isegid vähä, nüid södiveel täma eest ka. Uifle Alleksile, et ta ojaks ennast selle... mis ma soole rääkisi... eest.

Figure 1. A page from Pärt's autobiography where opinions of her acquaintances and the stories she has heard are in a different handwriting style. 
the (political, economical, and social) situation including what happened in the official sphere - the communal layer. ${ }^{10}$

3. The voice of power and self-legitimizing of the occupation regimes is expressed in the self-descriptive phraseology of the regimes and in the fragments of understanding the official history - institutional layer.

In our analysis of Pärt's text, we concentrated only on the totalitarian voice of the 1940 s and the 1950s.

The layered relationships of the personal and the communal to the official can be differentiated, on the basis of this autobiography, mainly according to the ratio of conscious intentionality (or absence) and according to the amount of folklorization. Expressions of Soviet working life are most probably less consciously used. Indeed, a comparison of different autobiographies from the collection of Estonian Life Histories demonstrates that the sphere of work acted as a channel between the official and the personal layers, and the usage of official phraseology occurs frequently in talking about working life. The way in which the author forbids the autobiography to express any official points of view, brings out the univocalism and authoritarianism of the institutional layer. This means that they do not comment, for example, on the status of either a $k u l a k^{11}$ or a bandit ${ }^{12}$, or any associated with Soviet society. These themes, and the convictions related to them, are considered self-explanatory and belong to the range of knowledge containing anti-Sovietism. Commenting on the institutional layer would be inappropriate for the author would demonstrate doubts as to the validity of their point of view. This self-understanding also forms a popular basis to the attitudes toward the personal files created by the Soviet powers after the collapse of Communism and revealing the contents of the KGB files - a problem we shall discuss below.

In Pärt's narrative, the reactions to the cult of Stalin as a supreme leader, to the ideological working culture propagated after the war, and to the radical restructuring of the habitual way of life are most strongly folklorized. Here, the opposition between the 'own' and the 'alien' is the strongest; the stress being laid on the conflict in the Soviet institutional level that is 'alien' and has no referentiality.

In analyzing the official Soviet phraseology and notions in a personal narrative, two contradictory tendencies occurred. On the one hand there is clear opposition not only through irony and parody but also through forbidding any relation at all, which also excludes challenging one's own convictions. On the other hand there is an inability to discuss the Soviet experience with nonSoviet phraseology (like in descriptions of tasks, the working environment, and conflicts in the workplace). The borderline between these tendencies need 
not always be very clear, which also points at the complexity with adaptation in autobiographical reminiscences.

\section{SOVIET PERSONAL FILE}

Analysis of the Soviet personal file enabled us to investigate how the relationship between the institutional, communal and personal layers during the Soviet period changed the 'point of view'. The autobiography presented the three layers from the perspective of the narrating person, whereas the personal file displays a person from the institutional viewpoint. We analyzed one file containing documents relevant to an accusation against two men. This contained questionnaires by the NKVD, interrogation protocols, correspondence between institutions and private individuals, etc. Both of the accused were Estonian Republic officials in the same commune and were dismissed when the Soviet order was put into force in Estonia in 1940; they were both employed again during the German occupation and arrested in 1945 after the reinstatement of the Soviet power. They were court-martialled according to $\$ 58$ of the Soviet Criminal Code (applied in analogous cases in $39.7 \%$ instances ${ }^{13}$ ). One of the men died in his first prison year; another was able to return to Estonia after staying in Siberia for 12 years. We have collected information about both men from people who knew them. In the following discussion however, we use only information connected with the man who survived Friedrich Samuel (19061982), the former commune elder of Kohtla ${ }^{14}$.

From the perspective of the current research we were mainly interested in how the dialogue between the institutional (official Soviet voice) and the personal (the men accused in anti-Soviet activities) took place. As the court file reflects a chronological process, covering the period of 1945-1994, we were also interested in the interactive adaptation of the participants in this dialogue.

The core of the official Soviet layer is first of all noticeable in the questionnaire describing the prisoners and also in the paragraph which convicted them. The contents of both are in direct conflict with how the accused interpret their own activities. The questionnaire in 1945, for example, did not allow answers from the perspective of a citizen of the Estonian Republic, which both commune executives had been for more than 20 years. The adjudicator's presupposition that both defendants lived in the Soviet Union is very apparent in the questionnaire and in the court's decision. This means that they should have lived according to the rules of the Russian Soviet Federative Socialist Republic even when Estonia was an independent state. Questions about serving in the 
army are a prime example, as the only possible choices for answers are: I served in the Red Army or I fought against the Red Army. ${ }^{15}$ The prosecutors also speak of both collaboration with the occupation regime and treason. The word 'occupation' was used without any attribution, as it only means the German occupation (at the same time, from the Estonian perspective, there were two occupations, the Soviet and Nazi occupation whereas both are described symmetrically ${ }^{\mathbf{1 6}}$ ). The core charge during the whole process is the betrayal of the home country. This is the point which starts Friedrich Samuel's interrogation. The accused denies betrayal. Even more so, when asked who else he could name as a traitor, he answers that he knows nothing about treason and knows nobody he could call a traitor. Such facts illustrate a serious conflict between the interpretation of activities and social roles on the institutional and personal level in 1945 . The contents of the court's decisions were generally not disclosed to the people. ${ }^{17}$ This is confirmed by the fact that, having survived imprisonment, Samuel applied for exoneration of the victims of Soviet repressions in 1963 and the widow of his colleague who died in the prison, also applied for exoneration 25 years later. By the 1960s, the survivor of repressions had achieved his purpose but only partially; the other man was exonerated, posthumously, at the end of the 1980s. The essence of the decision, from the aspect of the institution's adaptation, is important for it says "due to the lack of a proof of guilt" and that the man was only "an administrative official in the service of the German occupation regime". On the one hand, these documents prove that the official institutional voice did not become authoritative from the aspect of the personal layer although it had to be taken into account; on the other hand, the institutional level had to readjust its position under the pressure of the communal and personal level.

In the following we shall discuss whether the institutional layer in the court file is only represented in the official viewpoint or if it also appears outside that level. We shall return to the core accusation which is the betrayal of the home country as the men worked as commune administrators during the German occupation period. Several questions consequently arise as to the tasks of the commune administrators at the time. In these parts of the court file a conflict is apparent, and interconnects all three levels. Let us consider more closely the questions and answers about the activities of the commune elder and his deputy, and how the relations between the commune administrators and the people of the commune look according to those documents. As a rule, the tasks of the commune administrators are described in connection with meeting the food allotment norms or quota, etc. and supervising it during the German occupation. For example, an interrogation starts with the question in which "repressions" of the village people who failed to meet the food quota (and other 
such demands) did the commune elder participate in. The answer was, I reminded the people about it when they had not met the norms. In the material of the investigation there is a testimony of someone living in the village that the commune elder and his deputy strictly demanded that the people meet the food norms imposed by the German occupation regime. The witness says that those who did not meet the norms were threatened with being denounced to the authorities. The interrogator asks for the identities of anyone whom the men denounced. The witness cannot answer that question. In 1963, when the application for exoneration was handed in, the case was reopened to investigate once more the accusation that the commune elder repressed the local people in the matter of failing to meet the food norms of the German occupation regime. No concrete proof, was found during the investigation, as not one of the locals nor anyone of the members of their families had lodged a complaint ${ }^{18}$.

In the documents of the 1963 investigation the wartime commune appears as a wellfunctioning social system and not a system of repression put into practice by the parish administrators during the German occupation (an image created by the institutional 'voice', as expressed in the questions of the interrogator $^{19}$ ). For example, one of the witnesses cannot say that Samuel, being the commune elder, repressed these people from the village as a family member of someone who served in the Red Army during the war (the denial in the answer hints at the way the interrogating official set the question). Another witness says that he has heard nothing bad about the commune elder but knows, and names, those who Samuel helped in meeting the norms during the period. A third witness, a commune secretary of the period, claims that the commune people had no complaints about their elder: his relations with the local people were good and he was thought of as a good man.

In this instance, the institutional present (the Soviet point of view) and the past (the period of German occupation in retrospect) both demonstrate the conflict in the viewpoints of the two parties. The communal level appears in the utterances of the witnesses which describe the relations of the commune people and the administrators on the official level. The personal level shows itself in these parts of the testimony where personal qualities are mentioned in describing relations (he is spoken of as a good man) or the testimonies are made more specific by mentioning personal experience (I have heard nothing bad about him; or when the witness explains how the commune elder succeeded in decreasing quota for his father who had lost his wealth). The latter tendency to describe relations more exactly and positively becomes stronger in the material of 1963. This might have been caused by the novel way of putting the questions (let us remind you that the start of a new investigation 
was based on a claim that the accusation was invalid because no one had handed in a complaint. In addition, what happened in the 1960s was not considered a danger to anybody's life as it was in 1945). Then again, both the accused and the witnesses belonged to the same commune (both during the period of 19411944 and the 1945 and 1963 investigations), which within the context of normal relations between people did not give cause for confrontation in activities, decision, or utterances. ${ }^{20}$

Relations between the communal level and the institutional level become evident in how the utterances of the witnesses are interpreted by the Soviet official: they describe people's relations and attitudes while not noticing that they say things that the prosecutor can use either against the accused or the witness. For example, a testimony of the accused man's responsible work in the office of a commune elder is interpreted by the investigator as active support to the German occupation.

We may also place the argument of the accused against the accusations of the interrogator in 1945 in the communal level of the conflict of the interpretations of the local people and the Soviets. The interrogator claims that the accused joined a band of Forest Brothers ${ }^{21}$ and therefore is a "bandit". The man answers that he was in the woods, hiding there like all the other village people during the fierce battles. Communality here is involved in the war-time survival strategy of the village people which on the institutional level was interpreted as fighting against the Red Army. While the case was reinvestigated in 1963, the accused is already skilled in avoiding the "traps" of the official, institutional position, saying that all the village people had hidden themselves in the woods during the battles but were not armed. He now knows that, from the viewpoint of the Soviet regime, bandits were an armed group and evidently he did not know it before or think it necessary to consider it in another way. The officials believe his argument and drop the accusation.

The personal level not only appears in the descriptions of the document but also in the researchers' interpretation of the different reactions of the witnesses to the same, or analogous, questions. Earlier on we demonstrated how one man argued against the interrogator's theory of $a$ band of Forest Brothers. If we compare this to the answers of other witnesses, then according to the described reaction the witnesses do not argue but also do not use the phrase $a$ band of Forest Brothers in their answers. Such testimonies are interpreted by the representatives of the authorities as an affirmation of belonging to the band of Forest Brothers. While reinvestigating the case in 1963, the same witnesses are asked how utterances about belonging to the band of Forest Brothers had got into the testimony which they now deny, even though they acknowledge their signature on the document. One of the witnesses explains 
that he did not know Russian well and could not quite follow what was written in the protocol about belonging to the band of Forest Brothers. Another man who knows Russian well enough asserts that they have put it down in a wrong way, adding, I know that Samuel hid in the woods but about his belonging to the band I know nothing ${ }^{22}$. An interpretation of these statements is that the witness interrogated first did not know Russian either but disputed the prosecutor's theory from the very beginning. On the personal level both the adaptability of the men interrogated and the dangerous nature of the situation for the witness versus the accused, or even the ability to perceive and bear danger can be understood. There are also some quite natural qualities involved (a more argumentative or more acquiescent tone of dialogue as reflected in the documents).

Until now we have viewed the prosecutor as a representative of the institutional level and the accused, and the witnesses, as representatives of the communal and personal level. If we now shift the point of view, we must ask the question: in what way does the personality of the prosecutor make itself visible in the documents?

Prosecutors as individuals change in the course of the process; the witnesses, however, remain the same. This enables us to follow the viewpoint of the accused and the witnesses during the whole process, but prevents us from watching the personal aspect of the prosecution. On most occasions only the interrogator and the interrogated person met face-to-face. In 1945, the investigation was conducted by Aleksey Avgustovich Haruchi and in 1963 by Zhukov and Silkin. These are not Estonian names, which may show that these people had come to Estonia with the Soviet regime. This is important when we look at the prosecutor as an individual in a situation of conflict between images of history (especially when considering the understanding of the notion of a home country). In the interrogation protocols of 1945, the interrogating official takes a noticeably more rigid position than in the protocols of 1963. In the early years of the Soviet power an aggressive style is used while asking the questions (during interrogations that mostly took place at night). Some examples: "When did you become a member of the band of 'Forest Brothers'?" and an expression that was always used - "the military and fascist organisation Omakaitse (Self Defence)". In 1963, the questions are asked offering the interrogated person a choice: "describe what you have been charged of", "specify the circumstances of your being in the woods". As a rule, Omakaitse (Self Defence) is not called a military fascist organisation; simply "Omakaitse" or the neutral word "organisation" is used. The use of changes in language means that the interrogator's personality had nothing to do with it. The personality of the interrogator does not become apparent in the file we examined; he embodies 
in the document only a personified institution. When investigating sources of this type in a larger quantity, one of the questions would be whether such a result here demonstrates that the official's impersonality is an exception or a rule.

Individuals, who have been held in prison and describe interrogation situations in their narratives, categorize their interrogators as those who became physically violent and those who did not. In this file, beating the interrogated person or some other act of violence is not reflected. However the interrogated man confirms that he was beaten: we can read in the first interrogation protocol of 1963 that he explains his former admitting the charges with the fact that he was beaten twice under preliminary investigation. This is not taken into consideration as he cannot prove his claim. ${ }^{23}$ The official role of the interrogators is protected from the reader's eyes in these documents: there is no possibility of perceiving either their human characteristics or their methods of working. The document establishes the 'voice' of the Soviet regime as 'sterile', regimented, and controlled.

\section{CONCLUSION}

The central point of our discussion was the question about adaptation as dialectic of change and consistency, and more specifically a question about the complementary usage of sources of a different type in investigating adaptability during a longer period.

We concentrated on the complementary nature of two different sources, namely a Soviet personal file and a post-Soviet written autobiography, from the perspective of investigating oral history. We demonstrated that in both documents the institutional, communal, and personal layers are analytically differentiable, making those sources complementary. At the same time, the points of view these sources reflect are contrary: in the court file everything is framed into the official-political point of view with which the individual has to adapt. In the autobiography the institutional and the communal level are described from the personal point of view. Both sources speak of the effect of historical events on the lives of people and the different frames of the sources help to understand the complexity of adaptation in revealing instances where the institutional and the personal remain in opposite positions, in which knowledge of the official enables one to express personal aims, and in which adaptation occurs unconditionally.

Comparison of two very different types of sources was made possible because in both cases we put into the focus of the investigation the individual as 
an active agent and regarded the relations of the power and the individual through this agent. Portelli's model of the modes of history-telling, Bakhtin's idea of multivocalism, and Lotman's theory of semiosphere enabled us to view both texts in their inner and inter-relations, in their dialogue, and in their changeability. A complementary observation became possible due to the reinterpreting of possibilities of agency and dialogue in both sources. A change of the point of view was especially important when analyzing the court file for this is a type of source which up to now has been used in a way that opposes our method. The focus of investigation is in these cases the historical period in which the researchers investigate the conditions that started shaping people's lives.

After investigating the personal files of the Latvians from the point of view of the individual claims and referring to Bakhtin, Vieda Skultans concluded that the KGB documents are monologues, since they involve " $a$ denial of the equal rights of consciousness vis-à-vis truth" (Skultans 2001: 323). This is true, as we have demonstrated in the case of Friedrich Samuel's personal file. The institutional power has, in the file, and especially in the investigation transcripts, total control over the interpretation of the questions and the answers. Both the personal and the communal layer are reflected in those documents through the institutional layer. Nevertheless, we also saw in the file a dialogue between those layers from a diachronic perspective. Years later one of the parties took an opportunity to express his truth and found partial acceptance in the other (which is apparent in the reopening of the investigation of the case and also on the corrected verdict), and this transformed the relation of the two parties into a dialogue. The fact that the monologic aspect of the KGB files was brought to the fore in Skultans' treatment and the dialogical aspect was demonstrated in our example may have occurred because the sources we investigated were slightly different. In the Latvian examples analyzed by Skultans, those who wrote the protocols of the interrogation "translated" the answers of the interrogated persons more rigidly into official formulae than in our example. Additionally, the accused did not actively apply for reinvestigation later and for that reason the diachronic viewing of those files is not possible. ${ }^{24}$

In our example Friedrich Samuel applied for reinvestigation into his case almost twenty years after his conviction. During the whole process those who wrote the protocols probably did not check their language as rigidly as in the Latvian examples. We, therefore, have good reasons to speak about the agency in both senses as emphasized by Skultans (2001: 321-322), although naturally not in equal proportions. Samuel's agency, the manner in which Samuel behaved in the circumstances of his interrogation and his discontent at being found guilty, is expressed firstly as "being a subject of significance" and sec- 
ondly, as someone who tries to get strategic power by establishing his own meaning. Documents in Samuel's personal file (partly a result of his own agency) gave us an opportunity to view him as an active subject during the whole process. This is different from those people who Skultans investigated as she could only research agency in retrospect and ask questions about agency with inner moral self-regard. If we match Skultans' claim with Portelli's model of history-telling then we can see that in the Latvian KGB files the convicted persons' agency does not, in contrast to our example, appear on the Soviet institutional level.

From the perspective of adaptability, dialogue and monologue in Urve Pärt's autobiographical narrative are also meaningful. Although the purpose of this article was to elucidate the complementary nature of the two sources, it did not allow for investigation into these problems. We would still like to point out that with the way the institutional voice is presented as monologue in the autobiography, expression of agency may manifest this on a communal and personal level. Therefore Pärt, for example, does not comment on Soviet ideological and political categories such as 'kulak' and 'bandit', because the actual identity of the personal and the communal layers is in the denial of them and need not to be considered. At the same time, putting into uncritical use of the expressions of Soviet working life may demonstrate the strong referentiality of those expressions which point at a dialogue.

Finally, what supra-genre knowledge might the post-Soviet autobiography and the Soviet court file offer about social adaptability? Above all, both sources demonstrate a conflict: institutional, communal, and personal layers do not agree but the dynamics still exist. In this sense the present analysis makes it possible to view the conflict more profoundly. One of the outcomes of the close analysis was on the linguistic level: how far or how close the self-description is placed, first grammatically (e.g., the 'I' participating in the action $v s$ the undefined person or persons), secondly in using different notions (e.g., whether $I$ was in the woods or was a member of the band of Forest Brothers), and thirdly in creating imagery (e.g., irony, parody).

Our method of analysis made it possible to view the texts also from a supragenre point of view. Taking into account the genre specificity, it was still possible to compare texts of different character that were created in a different way on the personal, communal, and institutional level. As a result it appeared that, in the documents created by the Soviet powers, the agency of the repressed person is reflected even when control over the situation seems to be exclusively in the hands of the Soviet officials. This is an important result from the aspect of oral history. Sources created institutionally reflect processes, including the development of the Soviet Union, and its disintegration as a 
result of the actions of those in power. The political changes accompanying it, and people with their everyday practices, attitudes, or opinions, do not come into focus. Conversely, the autobiography demonstrated the presence and existence of the institutional language in the personal point of view which usually tends to remain in the background.

\section{COMMENTS}

1 The conference was organized by the Institute of History at the Jagiellonian University in Cracow, 8-10 November 2007 under the title "Oral History: The Art of Dialogue".

2 The Cracow report formed the basis of our article "(Re)constructing conflict and dialogue: oral history as a creative process", which will be published in the collection of conference materials. Funding for the research for both the present and the abovementioned article came from the project "Aspects of Terminology and Source Criticism in the Study of Everyday Culture" under the state program "Estonian Language and National Memory" and the ESF grant No. 6687. We are grateful to Kersti Unt for translating the article from Estonian to English and to Marcus Denton for exhaustive language editing.

${ }^{3}$ We divided the analytical work of both the Cracow and this report in the same way. Tiiu Jaago concentrated on the court files from the aspect of adaptation while Ene Kõresaar focused on the written autobiographies. We then worked together on the final analysis and conclusions.

4 We are especially grateful to Anne Heimo from the University of Turku who suggested Portelli's model for analysing our material. We are also grateful to Olaf Mertelsmann, a historian at the University of Tartu for his profound comments which helped us to explain the differences between the viewpoint of oral history and history and which made us go even deeper into putting into words the methodological aspects of oral history as a mode of research. We used Portelli's model at the 7th ESSCH Conference in Lisbon in February 2008 in the paper "The "truth of continuity" in Estonian oral history: negotiating the meaning of the 20th century". We should also like to express our gratitude to all participants of the Oral History session, who shared their thoughts and gave us feedback. The present article is a developed version of the Lisbon paper.

${ }^{5}$ Elina Makkonen (2006) has applied the same model in an interpretation of how people connected with the University of Joensuu, Finland described it as an institution, work and study environment as well as a personal period of life. More indirectly, others, like Pauliina Latvala (2005), used the model in her study of relationships between (family) history-telling and historiography in the late 1990s in Finland. Makkonen and Latvala selected for their analysis coherent sources. Our texts are incoherent, furthermore, our material tells of a painful and long-term conflict.

${ }^{6}$ The public appeal which was our primary method of collecting written life stories enables the researcher to indirectly guide the writer generally towards certain themes 
(cf. about thematic appeals or calls for autobiographic writing in Kõresaar 2005: 17 27), although the author's motivation and choice are still pre-eminent.

7 A researcher of autobiographies has different opportunities compared to a researcher of archive documents. If the autobiography has been written in the near past, as in our case, the author can be found and feedback obtained about the researcher's interpretation and understanding of the text. While working with Urve Pärt's autobiography, we contacted her both by phone and correspondence.

8 See, e.g., Jürjo 1996; Crimes of the Soviet Occupation 2007; Mandel 2007.

9 EKLA f. 350: 1809 Estonian Cultural History Archives, Urve Pärt's autobiography.

${ }^{10}$ Here the complexity of the communal layer in autobiography is demonstrated: 'communal' can at the same time be a village, working place, neighbourhood as well as the ethnic community if it is from the aspect of historical consciousness separated from the official, institutional level, a situation which characterizes the autobiographical reminiscences of Estonians of the the Soviet period.

11 The Soviet term 'kulak' denoted wealthier peasants who were persecuted \& deported in the process of collectivisation. In the Estonian context, the term was introduces during the annexation of the country in 1940.

12 Bandits - the post-war Soviet term for people vehemently opposed to the Soviet power, also applied to Forest Brothers.

${ }^{13}$ See Political Arrests in Estonia 1996: 477.

${ }^{14}$ A municipality in Northeast Estonia.

${ }^{15} \mathrm{Cf}$. in the questionnaire p. 17 (service in Red Army) and p. 18 (service in counterrevolutionary armies).

${ }^{16}$ Estonia was occupied both by the Soviet Union in 1940-1941 and Nazi Germany in 1941-1944. Estonians perceived both powers as alien. Furthermore, as battles also took place on the Estonian territory, these occupations are often described in autobiographies in comparison and together.

${ }^{17}$ We have already pointed at the incomprehensibility of the accusation for the accused. See also Vieda Skultans' (2001) discussion of how with the opening up of the KGB archives individuals enter into a retrospective dialogue with court files assembled about them.

18 ERAF.130SM-1-12640, p. 86.

${ }^{19}$ Cf. the discussion about how the individual's answers dissolve in the totalitarian language of the institution of the KGB files in Skultans 2001: 325ff.

${ }^{20}$ A change of relations within a community during the early years of the Soviet regime is one of the most serious themes: there are many stereotypical opinions (such as, no one was sent to the Siberia from our village for we had no envious people; no complaint, no judgement, etc); formulated experience (one had to be afraid of nasty people who talked too much; a wise village family never poked its nose into the private life of others); stories of how people saved one another or vice versa. To this theme, Estonian histo- 
rian Mati Mandel has dedicated research based on the Soviet interrogation transcripts. In the closing statement of his book he also explains his point of departure, [t] hose files reflect the smallness of people who are avaricious, vengeful, and traitorous. [---] The main idea of this book is to make us think about why it happened that an individual from Western Estonia acted in such evil manner against another and how to avoid everything that happened in 1940-1941 in the future. (Mandel 2007: 11)

${ }^{21}$ Forest Brothers or Estonian 'metsavennad', were partisans who sought refuge in the woods and waged guerilla war against the Soviet rule during and after the Second World War.

${ }^{22}$ Cf. ERAF. 130SM-1-12640, pp. 48, 92-97, 102-103.

${ }^{23}$ The source under discussion does not give direct evidence of the use of physical violence (there is only the witness' claim). If however, we take into account other sources and read the protocols of 1945, we might conclude these 'moments' from two circumstances. The first is that the length of the protocol and the time of interrogation are contradictory. The third interrogation lasted for two hours and twenty minutes, but the protocol fills only one and a half pages, which is considerably shorter than the other protocols. The second is the medical certificate that states that because of the poor health of the accused, he should do easier work. The certificate is placed in the file between the sixth and the last protocol and the final conviction (the placement being both as a document of the file and in the sense of the temporal occurrence of events).

${ }^{24}$ Skultans' aim is not to analyse the files but the reactions of the individuals when they read their files for the first time after the opening of the archives. Skultans could read those documents only with the help of a translator. So her analysis concentrated on the moments when her respondents argue the totality of the language of the documents and reclaim their identity as agents retrospectively in the post-Soviet period. Thus the cases analyzed by Skultans have some confluence with the post-Soviet autobiographical remembering which in our research is represented by Urve Pärt's autobiography.

\section{REFERENCES}

Bakhtin, Mikhail = Bahtin, Mihhail 1987. Teksti probleem lingvistikas, filoloogias ja humanitaarteadustes üldse. In: M. Bahtin. Valitud töid. Tallinn: Eesti Raamat, pp. 212-234. [In English: Bakhtin, Mikhail 1986 (1979). The Problem of the Text in Linguistics, Philology, and the Human Sciences: An Experiment in Philosophical Analysis. In: Caryl Emerson and Michael Holquist (eds.). Speech Genres and Other Late Essays. Transl. by Vern W. McGee. University of Texas Press Slavic Series 8. Austin: University of Texas Press, pp. 103-131.]

Burke, Peter 2004. History and Folklore: A Historiographical Survey. Folklore, Vol. 115, No. 2, pp. 133-139.

Crimes of Soviet Occupation in Estonia: deported, arrested, murdered 1940-1990: converged name register R1-R6. 2007. Nõukogude okupatsioonivõimu kuriteod Eestis: küüditatud, arreteeritud, tapetud 1940-1990: nimede koondregister R1-R6. Ed. by Leo Õispuu. Tallinn: Eesti Represseeritute Registri Büroo. 
Fingerroos, Outi; Haanpää, Riina; Heimo, Anne \& Peltonen, Ulla-Maija (eds.) 2006. Muistitietotutkimus: metodologisia kysymyksiä. [Ethnological research: methodological questions.] Tietolipas 214. Helsinki: Suomalaisen Kirjallisuuden Seura.

Grele, Ronald J. 2007. Reflections on the Practice of Oral History: Retrieving what we can from an earlier critique. In: Suomen Antropologi: Journal of the Finnish Anthropological Society, Vol. 32 (No. 4) Winter, pp. 11-23.

Jaago, Tiiu 2006. Pärimusliku ajaloo uurimine. [Research into oral narrative history.] In:Argikultuuri uurimise terminoloogia e-sõnastik. Tartu: Tartu Ülikooli eesti ja võrdleva rahvaluule osakond, available at http://argikultuur.e-uni.ee, last accessed on 13 April, 2008.

Jaago, Tiiu (ed.) 2001. Pärimuslik ajalugu. Tartu: Tartu Ülikooli Kirjastus. [In English: see next title.]

Jaago, Tiiu; Kõiva, Mare \& Kärsna, Kairika (eds.) 2002. Lives, Histories, and Identities: Studies on Oral History, Life- and Family Stories. Tartu: University of Tartu \& Estonian Literary Museum. Also available at http://lepo.it.da.ut.ee/ lehti/Oralhistory, last accessed on 13 April, 2008.

Jaago, Tiiu; Kõresaar, Ene \& Rahi-Tamm, Aigi 2006. Oral History and Life Stories as a Research Area in Estonian History, Folkloristic and Ethnology. In: Elore, 1 (13), pp. 1-15. Available at http://cc.joensuu.fi/ loristi/1_06/jkr1_06.pdf, last accessed on 13 April, 2008.

Jürjo, Indrek 1996. Pagulus ja Nõukogude Eesti. Vaateid KGB, EKP ja VEKSA arhiividokumentide põhjal. [Exile and the Soviet Estonia: Observations based on the archive documents of KGB, Estonian Communist Party and The Society for the Development of Cultural Ties with Estonians Abroad.] Tallinn: Umara.

Kõresaar, Ene 2005. Elu ideoloogiad: kollektiivne mälu ja autobiograafiline minevikutõlgendus eestlaste elulugudes. Eesti Muuseumi Sari 6. Summary: Ideologies of Life: Collective Memory and Autobiographical Meaning-Making of the Past in Estonian Post-Soviet Life Stories. Tartu: Eesti Rahva Muuseum.

Latvala, Pauliina 2005. Katse menneisyyteen: folkloristinen tutkimus suvun muistitiedosta. Summary: A glimpse into the past: A folkloristic investigation into oral history of the family. Suomalaisen Kirjallisuuden Seuran toimituksia 1024. Helsinki: Suomalaisen Kirjallisuuden Seura.

Lotman, Yuri M. 1999 = Lotman, Juri. Semiosfäärist. Tallinn: Vagabund. [In English: Lotman, Yuri 2005. On the semiosphere. (Transl. by Wilma Clark.) Sign Systems Studies Vol. 33, No. 1, pp. 215-239.]

Lotman, Yuri M. 1994. The Text within the Text. In: PMLA, Vol. 109 (No. 3), pp. 377-379.

Makkonen, Elina 2006. Instituution suullinen historia. [Institutions oral history] In: Fingerroos, Outi; Haanpää, Riina; Heimo, Anne \& Peltonen, Ulla-Maija (eds.). Muistitietotutkimus: metodologisia kysymyksiä. Tietolipas 214. Helsinki: Suomalaisen Kirjallisuuden Seura, pp. 245-270.

Mandel, Mati 2007. Kurjuse aasta Lõuna-Läänemaal 1940-1941. Summary: The year of evil in South Läänemaa in 1940-1941. Tallinn: Eesti Ajaloomuuseum.

Political Arrests in Estonia 1996 = Poliitilised arreteerimised Eestis 1940-1988 (\$58): Represseeritud isikute register, 1. Political Arrests in Estonia. 1940-1988 (\$58): Repressed Persons Records, 1. Tallinn: Eesti Represseeritute Registri Büroo \& Eesti Arhiiviamet \& Riigiarvutuskeskus \& Memento. 
Portelli, Alessandro 1997a. Oral History as Genre. In: The Battle of Valle Giulia: Oral History and the Art of Dialogue. University of Wisconsin Press, pp. 3-23.

Portelli, Alessandro 1997b. There's Gonna Always Be a Line: History-Telling as a Multivocal Art. In: The Battle of Valle Giulia: Oral History and the Art of Dialogue. University of Wisconsin Press, pp. 24-39.

Portelli, Alessandro 1992. History-Telling and Time: An Example from Kentucky. The Oral History Review, Vol. 20, No. 1/2, pp. 51-66.

Skultans, Vieda 2001. Arguing with the KGB Archives. Archival and Narrative Memory in Post-Soviet Latvia. Ethnos, Vol. 66, No. 3, pp. 320-343.

Thompson, Paul 2000 [1978]. The Voice of the Past: Oral History. New York: Oxford University Press.

Wertsch, James V. 2002. Voices of Collective Remembering. Cambridge \& New York: Cambridge University Press. 